\title{
Antibacterial activities of selected Cameroonian spices and their synergistic effects with antibiotics against multidrug-resistant phenotypes
}

\author{
Aimé G Fankam¹, Victor Kuete ${ }^{1 *}$, Igor K Voukeng ${ }^{1}$, Jules R Kuiate ${ }^{1}$ and Jean-Marie Pages ${ }^{2}$
}

\begin{abstract}
Background: The emergence of multi-drug resistant (MDR) phenotypes is a major public health problem today in the treatment of bacterial infections. The present study was designed to evaluate the antibacterial activities of the methanol extracts of eleven Cameroonian spices on a panel of twenty nine Gram negative bacteria including MDR strains.
\end{abstract}

Methods: The phytochemical analysis of the extracts was carried out by standard tests meanwhile the liquid micro-broth dilution was used for all antimicrobial assays.

Results: Phytochemical analysis showed the presence of alkaloids, phenols and tannins in all plants extracts. The results of the antibacterial assays indicated that all tested extracts exert antibacterial activities, with the minimum inhibitory concentration (MIC) values varying from 32 to $1024 \mathrm{\mu g} / \mathrm{ml}$. The extracts from Dichrostachys glomerata, Beilschmiedia cinnamomea, Aframomum citratum, Piper capense, Echinops giganteus, Fagara xanthoxyloïdes and Olax subscorpioïdea were the most active. In the presence of efflux pump inhibitor, PAßN, the activity of the extract from D. glomerata significantly increased on $69.2 \%$ of the tested MDR bacteria. At MIC/5, synergistic effects were noted with the extract of D. glomerata on $75 \%$ of the tested bacteria for chloramphenicol (CHL), tetracycline (TET) and norfloxacin (NOR). With B. cinnamomea synergy were observed on $62.5 \%$ of the studied MDR bacteria with $\mathrm{CHL}$, cefepime (FEP), NOR and ciprofloxacin (CIP) and $75 \%$ with erythromycin (ERY).

Conclusion: The overall results provide information for the possible use of the studied extracts of the spices in the control of bacterial infections involving MDR phenotypes.

\section{Background}

The emergence of MDR phenotypes is a major public health problem today in the treatment of bacterial infections. The multi-drug resistance of Gram negative bacteria is a major cause of morbidity and mortality in health care services [1]. The activation of bacterial efflux pumps also plays an important role in the appearance of resistance to antibiotics [2]. The real challenge for scientists worldwide today, is to continuously find new drugs to combat resistant microorganisms, or compounds which are able to inhibit the resistance mechanisms of pathogens, therefore restoring the activity of antibiotics. Medicinal plants are rich in compounds which may be potential natural drugs

\footnotetext{
* Correspondence: kuetevictor@yahoo.fr

'Department of Biochemistry, Faculty of science, University of Dschang, Cameroon

Full list of author information is available at the end of the article
}

and serve as alternative, less expensive and safe antimicrobials for the treatment of common ailments. Plant drugs are widely used in Africa for the treatment of many ailments and constitute the first health recourse for about $80 \%$ of the population [3]. A number of pharmaceutical products in current use worldwide are derived from plants [4]. In Cameroon, many medicinal plants including spices are used as herbal medicines. The present work was therefore designed to investigate the antibacterial potential against MDR bacteria of some of the commonly used medicinal spices in Cameroon such as Fagara xantoxyloides Watern., Dichrostachys glomerata (Forsk) Chuov, Olax subscorpioïdea Oliv., Solanum melongeua L. Var inerme D.C Hiern, Piper capense Lin.f, Xylopia aethiopica Dunal A. Rich., Aframomum citratum (Pereira). Schum, Scorodophloeus zenkeri Harms., Beilschmiedia cinnamomea (Stapf) Robyns \& Wilczek, Echinops giganteus A. Rich

\section{() Biomed Central}


and Mondia whitei (Hook F). Skell. This study was also extended to the evaluation of the potencies of the above plant extracts to increase the activity of some antibiotics on MDR bacteria. The role of bacterial efflux pumps in resistance to the extracts was also studied.

\section{Methods}

Plant materials and extraction

The eleven edible spices used in this work were purchased from Dschang local market, West Region of Cameroon in January 2010. The collected spices materials were: the fruits of Fagara xanthoxyloides, Dichrostachys glomerata, Olax subscorpiö̈dea, Solanum melongeua, Piper capense and Xylopia aethiopica, the bark of Aframomum citratum, Scorodophloeus zenkeri, Beilschmiedia cinnamomea and the roots of Echinops giganteus and Mondia whitei. The plants were identified by Mr. Fulbert Tadjouteu of the National herbarium (Yaoundé, Cameroon) where voucher specimens were deposited under the reference numbers (Table 1)

The air dried and powdered sample $(1 \mathrm{~kg})$ from each spice was extracted with methanol $(\mathrm{MeOH})$ for $48 \mathrm{~h}$ at room temperature. The extract was then concentrated under reduced pressure to give residues which constituted the crude extracts. They were then kept at $4^{\circ} \mathrm{C}$ until further use.

\section{Preliminary phytochemical investigations}

The major classes of secondary metabolites; alkaloids, anthocyanins, anthraquinones, flavonoids, phenols, saponins, tannins, steroids and triterpenes were screened according to the common phytochemical methods described by Harborne [5] with some modifications. Briefly, for alkaloids (5 mg plant extract in $10 \mathrm{ml}$ methanol); a portion of $2 \mathrm{ml}$ extract $+1 \% \mathrm{HCl}+$ steam, $1 \mathrm{ml}$ filtrate +6 drops of Mayor's reagents/Wagner's reagent/ Dragendroff reagent; creamish precipitate/brownish-red precipitate/orange precipitate indicated the presence of respective alkaloids. For tannins $(5 \mathrm{mg}$ plant extract in $10 \mathrm{ml}$ distilled water); a portion of $2 \mathrm{ml}+2 \mathrm{ml} \mathrm{FeCl}$; blue-black precipitate indicated the presence of tannins. For saponins (frothing test: $0.5 \mathrm{ml}$ filtrate $+5 \mathrm{ml}$ distilled water); frothing persistence indicated presence of saponins. For steroids and triterpenoids (Liebermann-Burchard reaction: $5 \mathrm{mg}$ plant extract in $10 \mathrm{ml}$ chloroform, filtered); a $2 \mathrm{ml}$ filtrate $+2 \mathrm{ml}$ acetic anhydride + conc. $\mathrm{H}_{2} \mathrm{SO}_{4}$. Blue-green ring or pink-purple indicated the presence of steroids or triterpenoids. For flavonoids (5 mg plant extract in $10 \mathrm{ml}$ methanol); a portion of $2 \mathrm{ml}+$ conc. $\mathrm{HCl}+$ magnesium; ribbon pink-tomato red color indicated the presence of flavonoids. For anthocyanins ( $5 \mathrm{mg}$ plant extract in $10 \mathrm{ml}$ methanol); a portion $2 \mathrm{ml}+1 \%$ $\mathrm{HCl}$ +heating; orange color indicated the presence of anthocyanins. For anthraquinones $(5 \mathrm{mg}$ plant extract in
$10 \mathrm{ml}$ methanol); a portion of $2 \mathrm{ml}+2 \mathrm{ml}$ ether-chloroform $1: 1 \mathrm{v} / \mathrm{v}+4 \mathrm{ml} \mathrm{NaOH} 10 \%(\mathrm{w} / \mathrm{v})$; red color indicated the presence of anthraquinones. For phenols ( $5 \mathrm{mg}$ plant material in $10 \mathrm{ml}$ methanol); a portion of $2 \mathrm{ml}+2 \mathrm{ml}$ $\mathrm{FeCl}_{3}$; violet-blue or greenish color indicated the presence of phenols.

\section{Chemicals for antimicrobial assays}

Tetracycline (TET), cefepime (FEP), streptomycin (STR), ciprofloxacin (CIP), norfloxacin (NOR), chloramphenicol (CHL), cloxacillin (CLX), ampicillin (AMP), erythromycin (ERY), kanamycin (KAN) (Sigma-Aldrich, St Quentin Fallavier, France) were used as reference antibiotics. $p$-Iodonitrotetrazolium chloride (INT) and phenylalanine arginine $\beta$-naphthylamide (PAßN) were used as microbial growth indicator and efflux pumps inhibitor respectively.

\section{Bacterial strains and culture media}

The studied microorganisms included reference (from the American Type Culture Collection) and clinical (Laboratory collection) strains of Providencia stuartii, Pseudomonas aeruginosa, Klebsiella pneumoniae, Escherichia coli, Enterobacter aerogenes and Enterobacter cloacae (Table 2). They were maintained on agar slant at $4^{\circ} \mathrm{C}$ and sub-cultured on a fresh appropriate agar plates $24 \mathrm{~h}$ prior to any antimicrobial test. Mueller Hinton Agar was used for the activation of bacteria. The Mueller Hinton Broth (MHB) was used for the MIC determinations.

\section{Bacterial susceptibility determinations}

The respective MICs of samples on the studied bacteria were determined using rapid INT colorimetric assay [6,7]. Briefly, the test samples were first dissolved in DMSO/ MHB. The solution obtained was then added to MHB, and serially diluted two fold (in a 96-wells microplate). One hundred microlitres $(100 \mu \mathrm{l})$ of inoculum $\left(1.5 \times 10^{6}\right.$ $\mathrm{CFU} / \mathrm{ml}$ ) prepared in $\mathrm{MHB}$ was then added. The plates were covered with a sterile plate sealer, then agitated to mix the contents of the wells using a shaker and incubated at $37^{\circ} \mathrm{C}$ for $18 \mathrm{~h}$. The final concentration of DMSO was lower than $2.5 \%$ and did not affect the microbial growth. Wells containing MHB, $100 \mu \mathrm{l}$ of inoculum and DMSO at a final concentration of $2.5 \%$ served as negative control (this internal control was systematically added). The total volume in each well was $200 \mu \mathrm{l}$. Chloramphenicol was used as reference antibiotic. The MICs of samples were detected after $18 \mathrm{~h}$ incubation at $37^{\circ} \mathrm{C}$, following addition $(40 \mu \mathrm{l})$ of $0.2 \mathrm{mg} / \mathrm{ml} \mathrm{INT}$ and incubation at $37^{\circ} \mathrm{C}$ for 30 minutes. Viable bacteria reduced the yellow dye to pink. MIC was defined as the lowest sample concentration that prevented this change and exhibited complete inhibition of microbial growth [8].

Samples were tested alone and then, in the presence of PAßN at $30 \mu \mathrm{g} / \mathrm{ml}$ final concentration. Two of the 
Table 1 Spices used in the present study and evidence of their activities.

\begin{tabular}{|c|c|c|c|}
\hline Spice samples (Family) & $\begin{array}{l}\text { Herbarium } \\
\text { Voucher } \\
\text { number }^{\mathrm{a}}\end{array}$ & Part used & $\begin{array}{l}\text { Bioactive (or potentially active) compounds }{ }^{b} \text { and screened activity }{ }^{c} \text { for } \\
\text { crude plant extract }\end{array}$ \\
\hline $\begin{array}{l}\text { Fagara xanthozyloïdes } \\
\text { Watern. (Rutaceae) }\end{array}$ & 21793/HNC/SRF & Fruits & $\frac{\frac{\text { Antimicrobial activity of essential oil [S: Ec, Bc, Bs, Af, Kp, Sa, Sf [19]; Cytotoxicity }}{\text { of fruits crude methanol extract [weak activity on leukemia CCRF-CEM and }}}{\text { CEM/ADR5000 cells, and pancreatic MiaPaCa-2 cell lines] [27] }}$ \\
\hline $\begin{array}{l}\text { Dichrostachys glomerata } \\
\text { (Forsk) chuov (Mimosaceae) }\end{array}$ & 15220/SRF-Cam & Bark, fruits & $\begin{array}{l}\text { Cytotoxicity of roots crude methanol extract [weak activity on leukemia CCRF- } \\
\text { CEM and CEM/ADR5000 cells, and pancreatic MiaPaCa-2 cell lines][27] }\end{array}$ \\
\hline $\begin{array}{l}\text { Aframomum citratum } \\
\text { (Pereira). Schum (Zingiberaceae) }\end{array}$ & 37736/SRF-Cam & Leaves, fruits & $\begin{array}{l}\text { Cytotoxicity of leaves crude methanol extract [weak activity on leukemia CCRF- } \\
\text { CEM and CEM/ADR5000 cells, and pancreatic MiaPaCa-2 cell lines] [27] }\end{array}$ \\
\hline $\begin{array}{l}\text { Beilschmiedia cinnamomea (Stapf) } \\
\text { Robyns \& Wilczek (Lauraceae) }\end{array}$ & 6933/SRF-Cam & Roots & / \\
\hline $\begin{array}{l}\text { Echinops giganteus } \\
\text { A. Rich. (Asteraceae) }\end{array}$ & 23647/SRF-Cam & Rhizomes & $\begin{array}{l}\frac{\text { Antimicrobial [lupeol sitosteryl; } \beta \text {-D-glucopyranoside] [28-31]; Cytotoxicity of }}{\text { hhizome crude methanol extract [Significant activity with IC }} \text { [So values of } 6.68 ; \\
7.96 \text { and } 9.84 \mu \mathrm{g} / \mathrm{ml} \text { respectively on leukemia CCRF-CEM cells, CEM/5000 cells } \\
\text { and pancreatic MiaPaCa-2 cell lines] [27] }\end{array}$ \\
\hline $\begin{array}{l}\text { Mondia whitei } \\
\text { (Hook F). Skell. (Periplocaceae) }\end{array}$ & $42920 / \mathrm{HNC}$ & Fruits & $\begin{array}{l}\text { Reproduction system [Roots water extract ( } 400 \mathrm{mg} / \mathrm{kg} / \text { day) for } 55 \text { days caused } \\
\text { testicular lesions resulting in the cessation of spermatogenesis, degenerative } \\
\text { changes in the somniferous tubules and epididymides in rats] [32] }\end{array}$ \\
\hline $\begin{array}{l}\text { Olax subscorpioidea } \\
\text { Oliv. (Olacaceae) }\end{array}$ & 3528/SRFK & Seeds & $\begin{array}{l}\text { Antibacterial and cytotoxic against Artemia salina [Santalbic acid] [33,34]; } \\
\text { Cytotoxicity of leaves crude methanol extract on cancer cells [weak activity on } \\
\text { leukemia CCRF-CEM and pancreatic MiaPaCa-2 cell lines and significant activity } \\
\text { with } \mathrm{IC}_{50} \text { of } 10.65 \mathrm{\mu g} / \mathrm{ml} \text { on CEM/ADR5000 cells] [27] }\end{array}$ \\
\hline $\begin{array}{l}\text { Solanum melongena L.Var inerme } \\
\text { D.C Hiern. (Solanaceae) }\end{array}$ & 22615/SRFC & Fruits & $\begin{array}{l}\text { Antimicrobial activity of methanol, dichloromethane and petrol ether extracts of } \\
\text { the fruits: [Q: } T m, T r, T t, C a \text { et } \mathrm{Tb}[35]\end{array}$ \\
\hline $\begin{array}{l}\text { Piper capense } \\
\text { Lin.f (Piperaceae) }\end{array}$ & 7650/SRF-Cam & Fruits & $\begin{array}{l}\text { Insecticidal [N-isobutyl-II-(3, 4-methylenedioxyphenyl)-2E, } 4 E, 10 E- \\
\text { undecatrienamide; N-pyrrolidyl-12-(3, 4-methylene-dioxyphenyl)-2E, } 4 E, 9 E, 11 Z- \\
\text { dodecatetraenamide; N-isobutyl-13-(3, 4-methylenedioxyphenyl)-2E, } 4 E, 12 E- \\
\text { tridecatrienamide; N-isobutyl-2E, 4E-decadienamide; N-isobutyl-2E, } 4 E- \\
\text { dodecadienamide] [36]; Cytotoxicity of fruit crude methanol extract [Significant } \\
\text { activity with IC } \mathrm{C}_{50} \text { values of } 7.02 ; 6.56 \text { and } 8.92 \mu \mathrm{m} / \mathrm{ml} \text { respectively on leukemia } \\
\text { CCRF-CEM cells, CEM/5000 cells and pancreatic MiaPaCa-2 cell lines] [27] }\end{array}$ \\
\hline $\begin{array}{l}\text { Xylopia aethiopica (Dunal) A. Rich. } \\
\text { (Annonaceae) }\end{array}$ & 16419/SRF-Cam & $\begin{array}{l}\text { Bark, leaves, } \\
\text { roots, seeds }\end{array}$ & $\begin{array}{l}\text { Antimicrobial [volatile oil of seeds] [19]; Antioxidant [volatile oil of seeds] [37]; } \\
\text { Cytotoxicity of seeds crude methanol extract [Significant activity with IC } C_{50} \\
\text { values of } 3.91 ; 7.4 \text { and } 6.86 \mu \mathrm{g} / \mathrm{ml} \text { respectively on leukemia CCRF-CEM cells, } \\
\text { CEM/5000 cells and pancreatic MiaPaCa-2 cell lines] [27] }\end{array}$ \\
\hline $\begin{array}{l}\text { Scorodophloeus zenkeri } \\
\text { Harms. (Caesalpinaceae) }\end{array}$ & 44803/SRF-Cam & Bark & $\begin{array}{l}\text { Antimicrobial: }[2,4,5,7 \text {-Tetrathiaoctane; 2, 4, 5, 6, 8-pentathianonane; 2, 3, 4, 6, } \\
\text { 8-pentathianonane; 2, 3, 5, 6, 8, 10-hexathiaundecane; 2, 3, 5-trithiahexane 5- } \\
\text { oxide; 2, 4, 5, 7-tetrathiaoctane 2-oxide; 2, 3, 5, 7-tetrathiaoctane 3, 3-dioxide; 2, } \\
\text { 3, 5-trithiahexane 3, 3-dioxide [38]; Cytotoxicity of bark crude methanol extract } \\
\text { on cancer cells [weak activity on leukemia CCRF-CEM and pancreatic MiaPaCa-2 } \\
\text { cell lines and significant activity with } \mathrm{IC}_{50} \text { of } 10.65 \mu \mathrm{g} / \mathrm{ml} \text { on CEM/ADR5000 } \\
\text { cells] [27] }\end{array}$ \\
\hline
\end{tabular}

a(HNC): Cameroon National Herbarium; (SRF): Société des reserves forestières; Cam: Cameroon; ${ }^{\mathrm{b}}(/)$ : Not reported

'[Screened activity: significant (S: CMI < $100 \mu \mathrm{g} / \mathrm{ml}$ ), moderate (M: $100<\mathrm{CMI} \leq 625 \mu \mathrm{g} / \mathrm{ml})$, Weak (W: CMI > $625 \mu \mathrm{g} / \mathrm{ml})$ Q: Qualitative activity based on the determination of inhibition zone [11,12]. Tm: Trichophyton mentagophytes; Tr: Trichophyton rubrum; Tt: Trichophyton tonsurans Tb: Trichosporon beigelii; Ca: Candida albicans; Ck: Candida krusei; Af: Aspergillus flavus; Bc: Bacillus cereus; Bs: Bacillus subtilis; Ec: Escherichia coli; Kp: Klebsiella pneumoniae; Sa: Staphylococcus aureus; Sf: Streptococcus faecalis.

best extracts [those from D. glomerata and B. cinnamo$m e a]$ were also tested in association with antibiotics at $\mathrm{MIC} / 2$ and $\mathrm{MIC} / 5$. These concentrations were selected following a preliminary assay on one of the tested MDR bacteria, P. aeruginosa PA124 (See Additional file 1, Table A1). All assays were performed in triplicate and repeated thrice. Fractional inhibitory concentration (FIC) was calculated as the ratio of $\mathrm{MIC}_{\text {Antibiotic in combi- }}$ nation $/ \mathrm{MIC}_{\mathrm{Antibiotic}}$ alone and the interpretation made as follows: synergistic $(<0.5)$, indifferent $(0.5$ to 4$)$, or antagonistic (>4) [9] (The FIC values available in Additional file 1, Tables A2 and A3).

\section{Results}

\section{Phytochemical composition of the spice extracts}

The results of the phytochemical studies (Table 3 ) showed that all the tested extracts contain alkaloids, phenols and tannins. Anthocyanins, anthraquinones, flavonoids, saponins, sterols and triterpenes were selectively present.

\section{Antibacterial activity of the spice extracts}

The results of the antibacterial activity of the extract alone on a panel of Gram negative bacteria are summarized in Table 4. It appears that the extract from 
Table 2 Bacterial strains and features

\begin{tabular}{|c|c|c|}
\hline Strains & Features & References \\
\hline \multicolumn{3}{|l|}{ Escherichia coli } \\
\hline $\begin{array}{l}\text { ATCC } 8739 \text { and } \\
\text { ATCC10536 }\end{array}$ & Reference strains & \\
\hline AG100 & Wild-type E. coli K-12 & [39] \\
\hline AG100A & AG100 $\triangle a C r A B:: K A N^{R}$ & [39] \\
\hline AG100A & $\triangle a c r A B$ mutant de $A G 100$, avec le gène acrF sur-exprimé; TET ${ }^{R}$ & [39] \\
\hline AG102 & $\triangle a c r A B$ mutant $A G 100$, owing acrF gene markedly over-expressed; $T^{2} T^{R}$ & [40] \\
\hline MC4100 & Wild type E. coli & \\
\hline W3110 & Wild type E. coli & [41] \\
\hline \multicolumn{3}{|l|}{$\begin{array}{l}\text { Enterobacter } \\
\text { aerogenes }\end{array}$} \\
\hline ATCC13048 & Reference strains & \\
\hline EA-CM64 & $\mathrm{CHL}^{\mathrm{R}}$ resistant variant obtained from ATCC13048 over-expressing the AcrAB pump & {$[42]$} \\
\hline EA3 & Clinical MDR isolate; $\mathrm{CHL}^{R}, \mathrm{NOR}^{R}, \mathrm{OFX}^{R}, \mathrm{SPX}^{R}, \mathrm{MOX}^{R}, \mathrm{CFT}^{R}, \mathrm{ATM}^{R}, \mathrm{FEP}^{R}$ & {$[42]$} \\
\hline EA27 & $\begin{array}{l}\text { Clinical MDR isolate exhibiting energy-dependent norfloxacin and } \\
\text { chloramphenicol efflux with } \operatorname{KAN}^{R} A M P^{R} \operatorname{NAL}^{R} \operatorname{STR}^{R} T^{R} T^{R}\end{array}$ & {$[42,43]$} \\
\hline EA289 & KAN sensitive derivative of EA27 & {$[43,44]$} \\
\hline EA294 & EA289 acrA::KAN ${ }^{R}$ & [44] \\
\hline EA298 & EA 289 to/C::KAN ${ }^{R}$ & [44] \\
\hline \multicolumn{3}{|l|}{$\begin{array}{l}\text { Enterobacter } \\
\text { cloacae }\end{array}$} \\
\hline ECCI69 & Clinical isolates & $\begin{array}{l}\text { Laboratory collection of UNR-MD1, } \\
\text { University of Marseille, France }\end{array}$ \\
\hline BM47 & Clinical isolates & $\begin{array}{l}\text { Laboratory collection of UNR-MD1, } \\
\text { University of Marseille, France }\end{array}$ \\
\hline BM67 & Clinical isolates & $\begin{array}{l}\text { Laboratory collection of UNR-MD1, } \\
\text { University of Marseille, France }\end{array}$ \\
\hline \multicolumn{3}{|l|}{$\begin{array}{l}\text { Klebsiella } \\
\text { pneumoniae }\end{array}$} \\
\hline ATCC12296 & Reference strains & \\
\hline KP55 & Clinical MDR isolate, $T E T^{R}, A_{M P^{R}}, A_{T M}^{R}, C_{E F}^{R}$ & [45] \\
\hline KP63 & Clinical MDR isolate, $\mathrm{TET}^{R}, \mathrm{CHL}^{\mathrm{R}}, \mathrm{AMP}^{R}, \mathrm{ATM}^{R}$ & [45] \\
\hline K24 & AcrAB-TolC & $\begin{array}{l}\text { Laboratory collection of UNR-MD1, } \\
\text { University of Marseille, France }\end{array}$ \\
\hline K2 & AcrAB-TolC & $\begin{array}{l}\text { Laboratory collection of UNR-MD1, } \\
\text { University of Marseille, France }\end{array}$ \\
\hline \multicolumn{3}{|l|}{ Providencia stuartii } \\
\hline NEA16 & Clinical MDR isolate, AcrAB-TolC & \\
\hline ATCC29914 & Clinical MDR isolate, AcrAB-TolC & [46] \\
\hline PS2636 & Clinical MDR isolate, AcrAB-TolC & \\
\hline PS299645 & Clinical MDR isolate, AcrAB-TolC & \\
\hline \multicolumn{3}{|l|}{$\begin{array}{l}\text { Pseudemonas } \\
\text { aeruginosa }\end{array}$} \\
\hline PA 01 & Reference strains & \\
\hline PA 124 & MDR clinical isolate & [26] \\
\hline
\end{tabular}

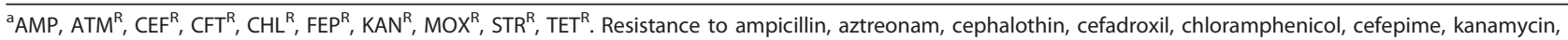
moxalactam, streptomycin, and tetracycline; MDR: Multidrug resistant.

D. glomerata was able to prevent the growth of all the twenty nine tested bacteria with MIC $\leq 1024 \mu \mathrm{g} / \mathrm{ml}$. All other samples showed selective activity; their inhibitory activity being recorded on 28 of the 29 (96.6\%) tested bacteria for B. cinnamomea, 24/29 (82.8\%) for A. citratum, $19 / 29$ (62.5\%) for P. capense, $18 / 29$ (62.1\%) for $E$. giganteus and F. Xanthoxylö̈des, 15/29 (51.7\%) for O. subscorpioïdea, 13/29 (44.8\%) for X. aethiopica, 12/29 (41.4\%) for M. whitei, 6/29 (20.7\%) for S. melongena and 4/29 (13, 79\%) for S. zenkeri.

MIC values below $100 \mu \mathrm{g} / \mathrm{ml}$ (Table 4) were recorded with the extract of B. cinnamomea against Enterobacter 
Table 3 Extraction yields, aspects and phytochemical composition of the plant extracts

\begin{tabular}{|c|c|c|c|c|c|c|c|c|c|c|c|}
\hline \multirow[t]{2}{*}{ Spice samples } & \multirow[t]{2}{*}{ Extraction yield* } & \multirow[t]{2}{*}{ Physical aspect } & \multicolumn{9}{|c|}{ Phytochemical composition } \\
\hline & & & Alkaloids & Anthocyanins & Anthraquinones & Flavonoids & Phenols & Saponins & Tannins & Sterols & Triterpenes \\
\hline Fagara xanthoxyloides & 12.13 & Oily brown & + & - & + & + & + & - & + & - & - \\
\hline Dichrostachys glomerata & 18.29 & Brown paste & + & + & + & + & + & + & + & + & + \\
\hline Aframomum citratum & 16.32 & Brown paste & + & - & - & + & + & + & + & + & - \\
\hline Beilschmiedia cinnamomea & 5.67 & Black paste & + & + & + & + & + & - & + & - & + \\
\hline Echinops giganteus & 8.87 & Oily brown & + & + & + & + & + & - & + & - & + \\
\hline Mondia whitei & 7.33 & Brown paste & + & + & + & + & + & + & + & + & + \\
\hline Olax subscorpioidea & 12.34 & Brown paste & + & - & + & + & + & - & + & - & + \\
\hline Solanum melongena & 14.30 & Black paste & + & + & + & + & + & + & + & + & + \\
\hline Piper capense & 12.87 & Brown paste & + & - & - & - & + & + & + & + & + \\
\hline Xylopia aethiopica & 26.42 & Brown paste & + & - & - & - & + & + & + & - & + \\
\hline Scorodophloeus zenkeri & 4.67 & Brown paste & + & - & - & - & + & + & + & - & + \\
\hline
\end{tabular}

(+): Present; (-): Absent; *The yield was calculated as the ratio of the obtained methanol extract according to the initial mass of the spice powder 
Table 4 Minimal inhibitory concentration (MIC) of the studied spice extracts and CHL on the studied bacterial species

\begin{tabular}{|c|c|c|c|c|c|c|c|c|c|c|c|c|}
\hline \multirow[b]{2}{*}{ Bacterial strains } & \multicolumn{12}{|c|}{ Tested samples and MIC in $\mu \mathrm{g} / \mathrm{ml}$ in the absence and presence of PAßN (in parenthesis) } \\
\hline & $\begin{array}{c}F . \\
\text { xanthoxyloides }\end{array}$ & $\begin{array}{c}D . \\
\text { glomerata }\end{array}$ & $\begin{array}{c}A . \\
\text { citratum }\end{array}$ & B. cinnamomea & $\begin{array}{c}E . \\
\text { giganteus }\end{array}$ & $\begin{array}{c}M . \\
\text { whitei }\end{array}$ & $\begin{array}{c}S . \\
\text { melongena }\end{array}$ & $\begin{array}{c}0 . \\
\text { subscorpioidea }\end{array}$ & $\begin{array}{c}P . \\
\text { capense }\end{array}$ & $\begin{array}{c}X . \\
\text { aethiopica }\end{array}$ & S. zenkeri & $\mathrm{CHL}$ \\
\hline \multicolumn{13}{|l|}{ E. coli } \\
\hline ATCC8739 & $-(1024)$ & $1024(512)$ & $1024(256)$ & $-(256)$ & $-(-)$ & $-(1024)$ & $-(128)$ & $-(-)$ & $-(512)$ & $-(512)$ & $-(-)$ & $4(<2)$ \\
\hline ATCC10536 & 1024 & $512(128)$ & 1024 & 1024 & 1024 & 1024 & - & 512 & 256 & 64 & 256 & $<2(<2)$ \\
\hline AG100 & 256 & $512(256)$ & 1024 (1024) & 1024 (1024) & 1024 (1024) & $1024(-)$ & $1024(-)$ & $512(-)$ & - (1024) & 1024 (1024) & $-(-)$ & $8(<2)$ \\
\hline AG100A & 1024 & $1024(256)$ & 1024 & 1024 & 1024 & - & - & 1024 & 1024 & - & - & $<2(<2)$ \\
\hline AG100A & - & $1024(512)$ & 1024 & 512 & 1024 & - & - & - & 1024 & 1024 & - & $64(<2)$ \\
\hline AG102 & 1024 & $512(256)$ & 1024 & 512 & 1024 & - & - & 1024 & 1024 & 1024 & - & $32(<2)$ \\
\hline MC4100 & 256 & $256(<8)$ & 512 & 256 & 512 & 1024 & 1024 & 1024 & 1024 & 1024 & - & 32 \\
\hline W3110 & $-(512)$ & $256(<8)$ & $512(<8)$ & $1024(<8)$ & 1024 (1024) & $1024(512)$ & - & $512(512)$ & 1024 (1024) & $-(-)$ & $-(-)$ & $4(<2)$ \\
\hline E. aerogenes & - & & & & & & & & & & & \\
\hline ATCC13048 & - & $512(512)$ & 1024 & 512 & - & - & - & - & - & - & - & $8(<2)$ \\
\hline CM64 & $-(-)$ & $512(512)$ & - (1024) & 1024 (1024) & 1024 (1024) & $1024(-)$ & $-(-)$ & $-(-)$ & $-(-)$ & $-(-)$ & $-(-)$ & $256(8)$ \\
\hline EA3 & 1024 & $1024(1024)$ & - & 1024 & - & - & - & 1024 & 1024 & - & - & - (128) \\
\hline EA27 & 1024 & $512(256)$ & 1024 & 1024 & 1024 & 1024 & - & 512 & 1024 & 1024 & - & $256(<2)$ \\
\hline EA289 & - & 1024 (1024) & 1024 & 512 & 1024 & - & - & - & - & - & - & - (64) \\
\hline EA298 & - & $1024(128)$ & - & 1024 & - & 1024 & - & 256 & 512 & 1024 & 128 & $64(<2)$ \\
\hline EA294 & 256 & 128 & 512 & 64 & 256 & - & 1024 & 256 & 256 & 256 & 512 & 8 \\
\hline \multicolumn{13}{|l|}{ E. cloacae } \\
\hline ECCI69 & $512(-)$ & 1024 (1024) & 1024 (1024) & 1024 (512) & $1024(-)$ & $-(-)$ & $-(-)$ & $-(-)$ & - & $-(1024)$ & $-(256)$ & $-(16)$ \\
\hline BM47 & 1024 (1024) & $1024(256)$ & 1024 (1024) & 1024 (1024) & $1024(-)$ & $-(-)$ & $-(-)$ & $-(-)$ & $512(64)$ & 1024(1024) & $-(-)$ & $-(<2)$ \\
\hline BM67 & 1024 (1024) & 1024 (128) & 1024 & 1024 & - & - & - & - & 512 & 1024 & - & $256(16)$ \\
\hline \multicolumn{13}{|l|}{ K. pneumoniae } \\
\hline ATCC11296 & 1024 (1024) & $512(128)$ & $512(512)$ & $256(256)$ & $1024(256)$ & $-(1024)$ & $-(1024)$ & 1024 (512) & $1024(256)$ & $-(-)$ & $-(-)$ & $4(<2)$ \\
\hline KP55 & 1024 & $512(256)$ & 1024 & 512 & - & - & - & 1024 & 1024 & - & - & $64(2)$ \\
\hline KP63 & 1024 & $512(<8)$ & 256 & 512 & 512 & 1024 & 512 & 256 & 256 & 64 & - & $64(<2)$ \\
\hline K24 & 512 & $512(32)$ & 512 & 256 & 32 & 1024 & 1024 & - & 1024 & - & - & $16(<2)$ \\
\hline K2 & - & 1024 (128) & - & 1024 & - & - & - & 1024 & 512 & - & - & $32(4)$ \\
\hline \multicolumn{13}{|l|}{ P. stuartuii } \\
\hline NEA16 & 1024 & $512(32)$ & 128 & 256 & 1024 & 1024 & 1024 & 512 & 256 & 512 & 1024 & $32(8)$ \\
\hline ATCC29914 & 1024 & $1024(512)$ & 512 & 512 & 1024 & 1024 & - & - & 1024 & - & - & $16(8)$ \\
\hline PS2636 & - & 512 & 1024 & 1024 & - & - & - & - & - & - & - & 32 \\
\hline PS299645 & $1024(-)$ & $256(256)$ & 256 & $256(512)$ & $-(-)$ & $-(-)$ & $-(512)$ & $-(-)$ & $-(-)$ & $-(-)$ & $-(-)$ & $32(<2)$ \\
\hline \multicolumn{13}{|l|}{$P$. aeruginosa } \\
\hline PA01 & - & 1024 (512) & 1024 & 1024 & - & - & - & - & - & 1024 & - & $16(<2)$ \\
\hline PA124 & - & $512(512)$ & - & 1024 & - & 1024 & - & - & - & - & - & $32(<2)$ \\
\hline
\end{tabular}


aerogenes EA294 $(64 \mu \mathrm{g} / \mathrm{ml})$, E. giganteus on Klebsiella pneumoniae $\mathrm{K} 24(32 \mu \mathrm{g} / \mathrm{ml})$ and $X$. aethiopica on Escherichia coli ATCC10536 and Klebsiella pneumoniae KP63 $(64 \mu \mathrm{g} / \mathrm{ml})$.

\section{Role of efflux pumps in susceptibility of Gram negative bacteria to the tested spice extracts}

The various strains and MDR isolates were tested for their susceptibilities to the spice extracts, and reference antibiotic, CHL in the presence of PAßN, a well-known efflux pump inhibitor. The results presented in Table 4 showed that the activity of the extract from $D$. glomerata significantly increased in the presence of PAßN on $18 / 26$ (69.2\%) of the tested bacteria. The MIC values below $100 \mu \mathrm{g} / \mathrm{ml}$ were noted with this extract against $E$. coli MC4100 and W3110 (<8 $\mathrm{\mu g} / \mathrm{ml})$, K. pneumoniae KP63 and $\mathrm{K} 24(<8 \mu \mathrm{g} / \mathrm{ml}$ and $32 \mu \mathrm{g} / \mathrm{ml}$ respectively) and P. stuartii NAE16 $(32 \mu \mathrm{g} / \mathrm{ml})$. Apart from the extract of D. glomerata, PAßN did not induce an increased activity of other tested extract.

\section{Effects of the association of some spice extracts with antibiotics}

To evaluate the possible synergistic effects of the extracts with antibiotics, four of the most active samples (F. xanthoxyloïdes, D. glomerata, B. cinnamomea and $O$. subscorpioïdea) were selected. A preliminary study using $P$. aeruginosa PA124, one of the MDR bacteria used in this work, was carried out with ten antibiotics (CLX, AMP, ERY, KAN, CHL, TET, FEP, STR, CIP and NOR) to select the appropriate sub-inhibitory concentrations to be used. The results (see Additional file 1, Table A1) allow the selection of $\mathrm{MIC} / 2$ and $\mathrm{MIC} / 5$ as the sub-inhibitory concentrations of the extracts from D. glomerata and B. cinnamomea, which were then tested on eight MDR bacteria, E. coli AG100, AG100 ${ }_{\mathrm{TET}}$, K. pneumoniae KP55, E. aerogenes EA3, EA27, EA289, CM64 in addition to $P$. aeruginosa PA124. The results are summarized in Tables 5 and 6. Synergistic effects were observed with the association between $D$. glomerata (Table 5, Additional file 1, Table A2) and B. cinnamomea (Table 6, Additional file 1 , Table A3) and most of the antibiotics on the studied MDR bacteria. At MIC/2, synergistic effects were noted with the extract of D. glomerata on $25 \%(2 / 8)$ of the tested bacteria for CLX and AMP, 50\% (4/8) for KAN, 62.5\% (5/ 8) for CHL, FEP, STR, CIP, 75\% (6/8) for ERY and 87.5\% $(7 / 8)$ for NOR and TET. Increase in MIC values of $>8$ fold were recorded at MIC/2 with CHL, TET, STR, CIP, NOR (Table 5). At MIC/5, synergistic effects were noted on $50 \%$ of the eight tested MDR bacteria in the case of STR and CIP, $62.5 \%$ in the case of ERY and $75 \%$ in the case of CHL, TET and NOR.

The extract of B. cinnamomea at MIC/2 (Table 6) also induced significant increase of the activity of several antibiotics, the synergistic effects being noted on $25 \%$ of the tested bacteria in the case of CLX and AMP, 50\% in the case of KAN, $62.5 \%$ in the case of FEP and STR, $75 \%$ in the case of CHL, TET and CIP, $87.5 \%$ in the case of ERY and $100 \%$ for NOR. With this extract, synergistic effects were also observed at MIC/5 on 25\% of the studied MDR bacteria in the case of CLX and AMP, $37.5 \%$ in the case of STR and KAN, 50\% in the case of TET, $62.5 \%$ in the case of CHL, FEP, NOR and CIP and $75 \%$ in the case of ERY.

\section{Discussion}

\section{Phytochemical composition of the spice extracts}

Phytochemical screening revealed the presence of several classes of secondary metabolites. Though the detection of such metabolites does not automatically predict the antimicrobial activity of a plant extract, it has clearly been demonstrated that several compounds belonging to the investigated classes of metabolites showed antibacterial activities [4,10-12].

\section{Antibacterial activity of the spice extract}

Phytochemicals are routinely classified as antimicrobials on the basis of susceptibility tests that produce MIC in the range of 100 to $1000 \mu \mathrm{g} / \mathrm{ml}$ [13]. Activity is considered to be significant if MIC values are below $100 \mu \mathrm{g} / \mathrm{ml}$ for crude extract and moderate when $100<\mathrm{MIC}<625$ $\mu \mathrm{g} / \mathrm{ml}[11]$. Therefore, the activity recorded with $B$. cinnamomea and E. giganteus respectively on E. aerogenes EA294 and K. pneumoniae K24, and X. aethiopica on E. coli ATCC10536 and K. pneumoniae KP63 can be considered significant. Alternative criteria have been described by Fabry et al. [14], which consider extracts having MIC values below $8000 \mu \mathrm{g} / \mathrm{ml}$ to have noteworthy antimicrobial activity. Under these less stringent criteria, and considering the fact that the spices tested are used as food ingredients with limited toxicity, the overall activity recorded with several extracts, most notably those of D. glomerata, B. cinnamomea, A. citratum, P. capense, E. giganteus, F. Xanthoxyloïdes and O. subscorpioidea, could be considered important. Besides, some of the tested samples were more active than CHL used as reference antibiotic on some of the MDR bacteria such as E. cloacae ECCI69 and BM47, E. aerogenes EA27 and EA289, highlighting the importance of the results reported herein. It can be noted that all the investigated phytochemical classes were detected in the extracts of D. glomerata, S. melongena and M. withei. Contrary to D. glomerata extract that exhibited a good spectrum of activity, the inhibition potential of S. melongena and $M$. withei was lower and seems not in correlation with their chemical composition. This clearly confirms the fact that the presence of secondary metabolites does not automatically predict the antimicrobial activity of a plant 
Table 5 Minimal inhibitory concentration (MIC) in $\mu \mathrm{g} / \mathrm{ml}$ of antibiotics in the absence and presence of the sub-inhibitory concentrations of $D$. glomerata extracts against MDR bacteria.

\begin{tabular}{|c|c|c|c|c|c|c|c|c|c|c|c|c|c|c|c|}
\hline \multirow[t]{3}{*}{ Bacterial strains } & \multicolumn{15}{|c|}{ Antibiotics and MIC in absence and presence $D$. glomerata extracts at $\mathrm{MIC} / 2$ and $\mathrm{MIC} / 5$} \\
\hline & \multicolumn{3}{|c|}{ Chloramphenicol } & \multicolumn{3}{|c|}{ Cloxacillin } & \multicolumn{3}{|c|}{ Ampicillin } & \multicolumn{3}{|c|}{ Erythromycin } & \multicolumn{3}{|c|}{ Kanamycin } \\
\hline & Alone & $\mathrm{MIC} / 2$ & $\mathrm{MIC} / 5$ & Alone & $\mathrm{MIC} / 2$ & $\mathrm{MIC} / 5$ & Alone & $\mathrm{MIC} / 2$ & $\mathrm{MIC} / 5$ & Alone & $\mathrm{MIC} / 2$ & $\mathrm{MIC} / 5$ & Alone & $\mathrm{MIC} / 2$ & $\mathrm{MIC} / 5$ \\
\hline PA124 & 32 & $32(1)^{\prime}$ & $16(2)^{s}$ & - & - & - & 64 & - & - & 64 & $32(2)^{s}$ & $64(1)^{1}$ & 64 & $16(4)^{s}$ & $64(1)$ \\
\hline CM64 & 256 & $256(1)^{\prime}$ & & & - & - & & & 256 & - & 64 & 128 & 1 & $1(1)^{\prime}$ & $1(1)^{\prime}$ \\
\hline EA3 & - & $32(>16)^{s}$ & $32(>16)^{s}$ & - & 256 & 256 & - & - & - & 64 & $32(2)^{s}$ & $64(1)^{\prime}$ & 32 & $16(2)^{s}$ & $16(2)^{s}$ \\
\hline EA27 & 256 & $32(8)^{s}$ & $64(4)^{s}$ & 256 & $64(4)^{s}$ & $64(4)^{s}$ & 64 & $64(1)^{\prime}$ & $64(1)^{\prime}$ & 32 & $32(1)^{\prime}$ & $32(1)^{\prime}$ & 16 & $16(1)^{\prime}$ & $16(1)^{\prime}$ \\
\hline EA289 & - & - & - & - & - & - & - & 256 & 64 & 256 & $64(4)^{s}$ & $128(2)^{s}$ & 4 & $<2(>2)^{s}$ & $4(1)^{\prime}$ \\
\hline KP55 & 64 & $8(8)^{\mathbf{s}}$ & $16(4)^{s}$ & - & - & - & - & - & - & 256 & $128(2)^{\mathbf{s}}$ & $128(2)^{s}$ & 32 & $32(1)^{1}$ & $32(1)^{\prime}$ \\
\hline AG100A $A_{\text {TET }}$ & 64 & $8(8)^{s}$ & $16(4)^{s}$ & - & - & - & - & 16 & 32 & 32 & $32(1)^{\prime}$ & $16(2)^{s}$ & 32 & $2(16)^{s}$ & $8(4)^{s}$ \\
\hline AG100 & 8 & $<2(>4)^{s}$ & $<2(>4)^{s}$ & 256 & $128(2)^{s}$ & $64(4)^{s}$ & 64 & $4(16)^{s}$ & $4(16)^{s}$ & 32 & $<2(>16)^{s}$ & $4(8)^{s}$ & $<2$ & $<2$ & $<2$ \\
\hline \multirow[t]{2}{*}{ Bacterial strains } & \multicolumn{3}{|c|}{ Tetracycline } & \multicolumn{3}{|c|}{ Cefepime } & \multicolumn{3}{|c|}{ Streptomycin } & \multicolumn{3}{|c|}{ Ciprofloxacin } & \multicolumn{3}{|c|}{ Norfloxacin } \\
\hline & Alone & $\mathrm{MIC} / 2$ & $\mathrm{MIC} / 5$ & Alone & $\mathrm{MIC} / 2$ & $\mathrm{MIC} / 5$ & Alone & $\mathrm{MIC} / 2$ & $\mathrm{MIC} / 5$ & Alone & $\mathrm{MIC} / 2$ & $\mathrm{MIC} / 5$ & Alone & $\mathrm{MIC} / 2$ & $\mathrm{MIC} / 5$ \\
\hline PA124 & 4 & $<0,5(>8)^{\mathbf{s}}$ & $2(2)^{s}$ & - & - & - & 16 & $16(1)^{\prime}$ & $16(1)^{\prime}$ & 16 & $<0,5(>8)^{\mathrm{s}}$ & $16(1)^{\prime}$ & 128 & - & - \\
\hline CM64 & 32 & $4(8)^{\mathrm{s}}$ & $8(4)^{s}$ & 256 & $64(4)^{s}$ & $128(2)^{s}$ & 8 & $<2(>4)^{\mathrm{s}}$ & $4(2)^{s}$ & 1 & $1(1)^{\prime}$ & $1(1)^{\prime}$ & 2 & $1(2)^{s}$ & $1(2)^{s}$ \\
\hline EA3 & 2 & $1(2)^{\mathbf{s}}$ & $2(2)^{s}$ & - & - & - & 16 & $8(2)^{\mathbf{s}}$ & $8(2)^{s}$ & 64 & $4(16)^{s}$ & $64(1)^{\prime}$ & 64 & $32(2)^{s}$ & $64(1)^{\prime}$ \\
\hline EA27 & 16 & $4(4)^{s}$ & $8(2)^{s}$ & 256 & $128(2)^{s}$ & $128(2)^{s}$ & 8 & $4(2)^{s}$ & $4(2)^{s}$ & 2 & $2(1)^{\prime}$ & $2(1)^{1}$ & 16 & $2(8)^{s}$ & $4(4)^{s}$ \\
\hline EA289 & 8 & $1(8)^{\mathbf{s}}$ & $2(4)^{s}$ & - & $256(>2)^{\mathbf{s}}$ & - & 64 & $8(8)^{\mathbf{s}}$ & $32(2)^{\mathbf{s}}$ & 32 & $16(2)^{s}$ & $16(2)^{s}$ & 64 & $16(4)^{s}$ & $32(2)^{\mathbf{s}}$ \\
\hline KP55 & 4 & $2(2)^{s}$ & $2(2)^{s}$ & - & $128(>4)^{s}$ & - & 8 & $8(1)^{\prime}$ & $8(1)^{\prime}$ & 128 & $4(32)^{s}$ & $32(4)^{s}$ & 128 & $32(4)^{s}$ & $32(4)^{s}$ \\
\hline AG100A $A_{\text {TET }}$ & 4 & $1(4)^{s}$ & $2(2)^{s}$ & - & $32(>16)^{s}$ & - & 16 & $2(8)^{s}$ & $16(1)^{\prime}$ & 64 & $32(2)^{s}$ & $16(4)^{s}$ & 64 & $8(8)^{s}$ & $16(4)^{s}$ \\
\hline AG100 & $<2$ & $<2(>4)^{s}$ & $<2(>4)^{s}$ & 256 & $<2(>128)^{\mathrm{s}}$ & $<2(>128)^{\mathrm{s}}$ & 256 & $256(1)^{\prime}$ & 256 (1) ' & $<2$ & $<2$ & $<2$ & 32 & $4(8)^{s}$ & $32(1)^{\prime}$ \\
\hline
\end{tabular}

$\mathrm{MIC} / 2$ : concentration of plant extract added equal to $256 \mu \mathrm{g} / \mathrm{ml}$ for PA124, CM64, EA3, EA27, KP55, AG100; and to $512 \mu \mathrm{g} / \mathrm{ml}$ for EA289 and AG100A

MIC/5: concentration of plant extract added equal to $102.4 \mu \mathrm{g} / \mathrm{ml}$ for PA124, CM64, EA3, EA27, KP55, AG100; and to $204.8 \mu \mathrm{g} / \mathrm{ml}$ for EA289 and AG100A TET

(): Values in bracket are folds increase of activity. S: synergy, I: indifference; (-): > $512 \mu \mathrm{g} / \mathrm{ml}$ 
Table 6 Minimal inhibitory concentration (MIC) of antibiotics in the absence and presence of the sub-inhibitory concentrations of $B$. cinnamomea extract ( $\mu$ g/ $\mathrm{ml}$ ) against some MDR bacteria.

\begin{tabular}{|c|c|c|c|c|c|c|c|c|c|c|c|c|c|c|c|}
\hline \multirow[t]{3}{*}{ Bacterial strains } & \multicolumn{15}{|c|}{ Antibiotics and MIC in absence and presence $B$. cinnamomea extracts at MIC/2 and MIC/5 } \\
\hline & \multicolumn{3}{|c|}{ Chloramphenicol } & \multicolumn{3}{|c|}{ Cloxacillin } & \multicolumn{3}{|c|}{ Ampicillin } & \multicolumn{3}{|c|}{ Erythromycin } & \multicolumn{3}{|c|}{ Kanamycin } \\
\hline & Alone & $\mathrm{MIC} / 2$ & $\mathrm{MIC} / 5$ & Alone & $\mathrm{MIC} / 2$ & $\mathrm{MIC} / 5$ & Alone & $\mathrm{MIC} / 2$ & $\mathrm{MIC} / 5$ & Alone & $\mathrm{MIC} / 2$ & $\mathrm{MIC} / 5$ & Alone & $\mathrm{MIC} / 2$ & $\mathrm{MIC} / 5$ \\
\hline PA124 & 32 & $<0,5(>32)^{\mathbf{s}}$ & $32(1)^{\mathbf{s}}$ & - & - & - & - & - & - & 64 & $8(8)^{\mathbf{s}}$ & $32(2)^{s}$ & 32 & $32(1)$ & 64 \\
\hline CM64 & 256 & - & - & - & - & - & - & - & - & - & $64(>8)^{\mathbf{s}}$ & $64(>8)^{s}$ & 1 & $<0.5(>2)^{\mathbf{s}}$ & $<0.5(>2)^{s}$ \\
\hline EA3 & - & $16(>32)^{s}$ & 32 & - & 256 & - & - & - & - & 64 & $8(8)^{s}$ & $32(2)^{s}$ & 32 & $16(2)^{s}$ & $16(2)^{s}$ \\
\hline EA27 & 256 & $8(32)^{s}$ & $16(16)^{s}$ & 256 & $<0,5(>512)^{s}$ & $16(16)^{s}$ & 64 & $64(1)^{\prime}$ & $64(1)^{\prime}$ & 32 & $8(4)^{s}$ & $32(2)^{s}$ & 16 & $<0.5(>32)^{\mathrm{s}}$ & $16(1)^{\prime}$ \\
\hline EA289 & - & 256 & - & - & - & & - & - & - & 256 & $32(8)^{s}$ & $64(4)^{s}$ & 4 & $4(1)^{\prime}$ & $4(1)^{\prime}$ \\
\hline KP55 & 64 & $8(8)^{s}$ & $8(8)^{\mathbf{s}}$ & - & - & - & - & - & - & 256 & $128(2)^{\mathbf{s}}$ & $128(2)^{\mathbf{s}}$ & 32 & $32(1)^{\prime}$ & $32(1)^{\prime}$ \\
\hline AG100A $A_{T E T}$ & 64 & $16(4)^{s}$ & $32(2)^{s}$ & - & $128(>4)^{S}$ & $128(>4)^{S}$ & - & $8(>64)^{s}$ & $32(16)^{s}$ & 32 & $32(1)^{\prime}$ & $32(1)^{\prime}$ & 32 & $1(32)^{\mathbf{s}}$ & $8(4)^{5}$ \\
\hline AG100 & 8 & $<2(>4)^{s}$ & $4(2)^{s}$ & 256 & $256(1)$ & $256(1)$ & 64 & $<2(>32)^{\mathbf{s}}$ & $4(16)^{s}$ & 32 & $<2(>16)^{s}$ & $4(8)^{s}$ & $<2$ & $<2$ & $<2$ \\
\hline \multirow[t]{2}{*}{ Bacterial strains } & \multicolumn{3}{|c|}{ Tetracycline } & \multicolumn{3}{|c|}{ Cefepime } & \multicolumn{3}{|c|}{ Streptomycin } & \multicolumn{3}{|c|}{ Ciprofloxacin } & \multicolumn{3}{|c|}{ Norfloxacin } \\
\hline & Alone & $\mathrm{MIC} / 2$ & $\mathrm{MIC} / 5$ & Alone & $\mathrm{MIC} / 2$ & $\mathrm{MIC} / 5$ & Alone & $\mathrm{MIC} / 2$ & $\mathrm{MIC} / 5$ & Alone & $\mathrm{MIC} / 2$ & $\mathrm{MIC} / 5$ & Alone & $\mathrm{MIC} / 2$ & $\mathrm{MIC} / 5$ \\
\hline PA124 & 4 & $2(2)^{s}$ & $4(1)^{s}$ & - & $64(>8)^{s}$ & - & 16 & $16(1)$ & $16(1)$ & 16 & $16(1)^{\prime}$ & $16(1)^{\prime}$ & 128 & $64(2)^{s}$ & $64(2)^{s}$ \\
\hline CM64 & 32 & $8(4)^{s}$ & $8(4)^{s}$ & 256 & $32(8)^{\mathbf{s}}$ & $32(8)^{\mathbf{s}}$ & 8 & $<2(>4)^{\mathrm{s}}$ & $<2(>4)^{s}$ & 1 & $1(1)^{\prime}$ & $1(1)^{\prime}$ & 2 & $1(2)^{s}$ & $2(1)^{\prime}$ \\
\hline EA3 & 2 & $1(2)^{s}$ & $2(1)^{\prime}$ & - & - & - & 16 & $4(4)^{s}$ & $4(4)^{s}$ & 64 & $4(16)^{s}$ & $8(8)^{s}$ & 64 & $16(4)^{s}$ & $32(2)^{s}$ \\
\hline EA27 & 16 & $1(16)^{s}$ & $4(4)^{s}$ & 256 & $16(16)^{s}$ & $64(4)^{s}$ & 8 & $<0.5(>16)^{\mathrm{s}}$ & $2(4)^{s}$ & 2 & $<0.5(>4)^{\mathrm{s}}$ & $2(1)^{\prime}$ & 16 & $<0.5(>32)^{\mathrm{s}}$ & $4(4)^{s}$ \\
\hline EA289 & 8 & $4(2)^{s}$ & $4(2)^{s}$ & - & $256(>2)^{s}$ & $256(>2)^{s}$ & 64 & $16(4)^{s}$ & $64(1)^{\prime}$ & 32 & $16(2)^{s}$ & $16(2)^{s}$ & 64 & $32(2)^{s}$ & $32(2)^{s}$ \\
\hline KP55 & 4 & $4(1)^{1}$ & $4(1)^{\prime}$ & - & $64(>8)^{s}$ & $128(>2)^{s}$ & 8 & $8(1)^{\prime}$ & $8(1)^{\prime}$ & 128 & $8(16)^{\mathrm{s}}$ & $16(8)^{s}$ & 128 & $16(8)^{s}$ & $32(4)^{s}$ \\
\hline AG100A & 4 & $2(2)^{s}$ & $2(2)^{s}$ & - & $256(>2)^{s}$ & $64(>4)^{s}$ & 16 & $8(2)^{\mathbf{s}}$ & $16(1)^{\prime}$ & 64 & $4(16)^{s}$ & $8(8)^{s}$ & 64 & $32(2)^{s}$ & $64(1)^{\prime}$ \\
\hline AG100 & $<2$ & $<2$ & $<2$ & 256 & $64(4)^{s}$ & $64(4)^{s}$ & 256 & $256(1)^{\prime}$ & $256(1)^{\prime}$ & 4 & $<2(>2)^{\mathbf{s}}$ & $<2(>2)^{\mathbf{s}}$ & 32 & $4(8)^{s}$ & $32(1)^{\prime}$ \\
\hline
\end{tabular}

MIC/2: concentration of plant extract added equal to $512 \mu \mathrm{g} / \mathrm{ml}$ for PA124, CM64, EA3, EA27, AG100; and to $256 \mu \mathrm{g} / \mathrm{ml}$ for EA289, KP55 and AG100A TET

MIC/5: concentration of plant extract added equal to $204.8 \mu \mathrm{g} / \mathrm{ml}$ for PA124, CM64, EA3, EA27, KP55, AG100; and to102.4 $\mu \mathrm{g} / \mathrm{ml}$ for EA289 and AG100A

(): Values in bracket are folds increase of activity. S: synergy, I: indifference; (-): $>512 \mu \mathrm{g} / \mathrm{ml}$ 
extract though it is a good indication of its possible pharmacological potential.

To the best of our knowledge, the antibacterial activity of $B$. cinnamomea and $P$. capense is being reported for the first time. Moreover, the present work reports for the first time the activity of the tested spices on MDR bacteria. Nevertheless, the antimicrobial potential of some of the plants or related genus were demonstrated on sensitive strains. Banso and Adeyemo [15] reported the presence of antibacterial tannins in the genus Dichrostachys. Chouna et al. [16] also demonstrated that Beilschmiedia anacardioides was significantly active against Bacillus subtilis, Micrococcus luteus and Streptococcus faecalis. Plants of the genus Echinops such as E. ellenbeckii and E. longisetus were found active on Staphylococcus aureus [17] meanwhile the antibacterial activity of the essential oils and alkaloids from $F$. xanthoxyloides was also documented $[18,19]$. The aqueous and ethanol extracts from O. subscorpioïdea were found active on both bacteria and fungi [20]. The results obtained in the present work therefore provide additional information on the studied plants and are in consistence with some of the previous reports.

\section{Role of efflux pumps in susceptibility of Gram negative bacteria to the tested spice extracts}

Tripartite efflux systems, mainly those clinically described as AcrAB-TolC in Enterobacteriaceae or MexAB-OprM in $P$. aeruginosa, are associated with a major human health problem as they play a central role in multidrug resistance of pathogenic Gram negative bacteria [21-23]. PAßN has been reported as a potent inhibitor of the RND efflux systems and is especially active on AcrAB-TolC and MexABOprM $[22,24,25]$. To determine the role of efflux pumps in this work, the concentration of PAßN used $(30 \mu \mathrm{g} / \mathrm{ml})$ had no intrinsic effect on the bacteria as previously determined [26]. In contrast, with these conditions significant increase of the antibacterial activity of $D$. glomerata extract was noted, showing that one or more active compounds from this plant could be substrate(s) of efflux pumps acting in resistant strains of E. coli, K. pneumoniae and $P$. stuartii. These data suggest that possible association of the extract of D. glomerata and efflux pump inhibitor can be envisaged to improve the fight against MDR phenotypes.

\section{Effects of the association of extracts from $D$. glomerata and $B$. cinnamomea with antibiotics}

The association of natural products such as plant extracts and antibiotics constitutes an alternative in the fight against MDR bacteria. Significant synergistic effects were noted with both $D$. glomerata and B. cinnamomea extracts when they were associated with several antibiotics. Such effects might be due either to the action of the active compounds or possible inhibition of the efflux pumps by other compounds of the extracts. The lowest synergistic effects were observed with $\beta$-lactamines (CLX and AMP), obviously due to the fact their target are localized in the bacterial cell coat. However, the synergistic effects observed indicate that active compounds of the extract could also present different mode(s) of action from those of the studied antibiotics.

\section{Conclusion}

The overall results of the present work provide baseline information for the possible use of the studied spice extracts in the treatment of bacterial infections involving MDR phenotypes. In addition to these antibacterial activities, the data reported herein indicated that possible combinations of the extract of D. glomerata with an efflux pump inhibitor, and also the association of extract of this plant as well as that from B. cinnamomea with several antibiotics could be used in the control of bacterial infections involving MDR phenotypes.

\section{Additional material}

Additional file 1: Table S1. Activities of antibiotics in combination with the sub-inhibitory concentrations of some plants extracts on Pseudomonas aeruginosa PA124. Table S 2. Fractional Inhibitory Concentrations (FIC) of the association between antibiotics and extract of D. glomerata at MIC/2 and MIC/5 $(\mu \mathrm{g} / \mathrm{ml})$ against MDR bacteria. Table S 3. Fractional Inhibitory Concentrations (FIC) of association between antibiotics and extract of B. cinnamomea at $\mathrm{MIC} / 2$ and $\mathrm{MIC} / 5(\mu \mathrm{g} / \mathrm{ml})$.

\section{Acknowledgements}

Authors are thankful to the Cameroon National Herbarium (Yaounde) for plants identification and Mr. Paul K. Lunga and Dr Gerald Ngo Teke for language editing.

\section{Author details}

${ }^{1}$ Department of Biochemistry, Faculty of science, University of Dschang, Cameroon. ${ }^{2}$ Transporteurs Membranaires, Chimiorésistance et Drug Design, UMR-MD1, IFR 88, UFRs de Médecine et de Pharmacie, Marseille, France.

\section{Authors' contributions}

PAF carried out the study; VK designed the experiments and wrote the manuscript; VK, IKV, JRK and JMP supervised the work; VK and JMP provided the bacterial strains; All authors read and approved the final manuscript.

\section{Competing interests}

The authors declare that they have no competing interests.

Received: 4 August 2011 Accepted: 1 November 2011 Published: 1 November 2011

\section{References}

1. Kamicker BJ, Sweeney MT, Kaczmarek F, Dib-Hajj F, Shang W, Crimin K, Duignan J, Gootz TD: Bacteria efflux pomp inhibitors. Methods Mol Med 2008, 142:187-204

2. Lutz JK, Lee J: Prevalence and Antimicrobial-Resistance of Pseudomonas aeruginosa in Swimming Pools and Hot Tubs. Int J Environ Res Public Health 2011, 8:554-564.

3. Sofowora A: 1993. Medicinal Plants and Traditional Medicine in Africa. Ibadan, Spectrum Books Limited; 1993. 
4. Cowan MM: Plant products as antimicrobial agents. Clinical Microbiology Reviews 1999, 12:564-582

5. Harborne JB: Phytochemical Methods. New York, Chapman and Hall; 1973.

6. Eloff JN: A sensitive and quick microplate method to determine the minimal inhibitory concentration of plant extracts for bacteria. Planta Med 1998, 64:711-713.

7. Mativandlela SPN, Lall N, Meyer JJM: Antifungal and antitubercular activity of (the roots of) Pelargonium reniforme (CURT) and Pelargonium sidoides (DC) (Geraniaceae) root. S Afr J Bot 2006, 72:232-237.

8. Kuete V, Ngameni B, Fotso Simo CC, Kengap Tankeu R, Tchaleu Ngadjui B, Meyer JJM, Lall N, Kuiate JR: Antimicrobial activity of the crude extracts and compounds from Ficus chlamydocarpa and Ficus cordata (Moraceae). J Ethnopharmacol 2008, 120:17-24.

9. Coutinho HD, Vasconcellos A, Freire-Pessôa HL, Gadelha CA, Gadelha TS, Almeida-Filho GG: Natural products from the termite Nasutitermes corniger lower aminoglycoside minimum inhibitory concentrations. Pharmacogn Mag 2010, 6:1-4.

10. Bruneton J: Pharmacognosie: Phytochimie, Plantes medicinales. Paris, Tec \& Doc; 3 1999, 263-309.

11. Kuete V: Potential of Cameroonian plants and derived-products against microbial infections: A review. Planta Med 2010, 76:1479-1491.

12. Kuete V, Efferth T: Cameroonian medicinal plants: Pharmacology and derived natural products. Front Pharmacol 2010, 1:1-19.

13. Simões M, Bennett RN, Rosa EA: Understanding antimicrobial activities of phytochemicals against multidrug resistant bacteria and biofilms. Nat Prod Rep 2009, 26:746-757.

14. Fabry W, Okemo PO, Ansorg R: Antibacterial activity of East African medicinal plants. J Ethnopharmacol 1998, 60:79-84.

15. Banso A, Adeyemo SO: Evaluation of antibacterial properties of tannins isolated from Dichrostachys cinerea. Afr J Biotech 2007, 6:1785-1787.

16. Chouna JR, Nkeng-Efouet PA, Lenta BN, Devkota PK, Neumann B, Stammler HG, Kimbu SF, Sewald N: Antibacterial endiandric acid derivatives from Beilschmiedia anacardioides. Phytochemistry 2009, 70:684-688.

17. Hymete A, Iversena TH, Rohloff J, Erkob B: Screening of Echinops ellenbeckii and Echinops longisetus for biological activities and chemical constituents. Phytomedicine 2005, 12:675-679.

18. Chaaib F, Queiroz EF, Ndjoko K, Diallo D, Hostettmann K: Antifungal and antioxidant compounds from the root bark of Fagara zanthoxyloides. Planta Med 2003, 64:616-320

19. Tatsadjieu LN, Essia Ngang JJ, Ngassoum MB, Etoa FX: Antibacterial and antifungal activity of Xylopia aethiopica, Monodora myristica, Zanthoxylum xanthoxyloides and Zanthoxylum leprieurii from Cameroon. Fitoterapia 2003, 74:469-472.

20. Ayandele AA, Adebiyi AO: The phytochemical analysis and antimicrobial screening of extracts of Olax subscorpioïdea. Afr J Biotech 2007, 6:868-870.

21. Blot S, Depuydt P, Vandewoude K, De Bacquer D: Measuring the impact of multidrug resistance in nosocomial infection. Curr Opin Infect Dis 2007, 20:391-396.

22. Pietras A, Bavro VN, Furnham N, Pellegrini-Calace M, Milner-White EJ, Luisi BF: Structure and mechanism of drug efflux machinery in Gram negative bacteria. Curr Drug Target 2008, 9:719-728.

23. Papadopoulos CJ, Carson CF, Chang BJ, Riley TV: Role of the MexAB-OprM efflux pump of Pseudomonas aeruginosa in tolerance to tea tree (Melaleuca alternifolia) oil and its monoterpene components terpinen-4ol, 1, 8-cineole and $a$-terpineol. Appl Environ Microbiol 2008, 74:1932-1935.

24. Lomovskaya O, Bostian KA: Practical applications and feasibility of efflux pump inhibitors in the clinic-a vision for applied use. Biochem Pharmacol 2006, 71:910-918.

25. Pagès J-M, Lavigne JP, Leflon-Guibout $V$, Marcon $E$, Bert $F$, Noussair $L$, Nicolas-Chanoine MH: Efflux Pump, the Masked Side of $\beta$-Lactam Resistance in Klebsiella pneumoniae Clinical Isolates. PLOS ONE 2009, 4 e4817.

26. Lorenzi V, Muselli A, Bernardini AF, Berti L, Pagès JM, Amaral L, Bolla JM: Geraniol restores antibiotic activities against multidrug-resistant isolate from Gram-negative species. Antimicrob Agents Chemother 2009, 53:2209-2211.

27. Kuete V, Krusche B, Youns M, Voukeng I, Fankam AG, Tankeo S, Lacmata S, Efferth T: Cytotoxicity of some Cameroonian spices and selected medicinal plant extracts. J Ethnopharmacol 2011, 134:803-812.
28. Kojima H, Sato N, Hatano A, Ogura H: Sterol glucosides from Prunella vulgaris. Phytochemistry 1990, 29:2351-2355.

29. Tane P, Bergquist K-E, Tene M, Ngadjui BT, Ayafor JF, Sterner O: Cyclodione, an unsymmetrical dimeric diterpene from Cylicodiscus gabunensis. Tetrahedron 1995, 51:11595-11600.

30. Kuete V, Eyong KO, Folefoc GN, Beng VP, Hussain H, Krohn K, Nkengfack AE Antimicrobial activity of the methanolic extract and of the chemical constituents isolated from Newbouldia laevis. Pharmazie 2007, 62:552-556.

31. Kuete V, Wansi JD, Mbaveng AT, Kana Sop MM, Tcho Tadjong A, Beng VP, Etoa FX, Wandji J, Marion Meyer JJ, Lall N: Antimicrobial activity of the methanolic extract and compounds from Teclea afzelii (Rutaceae). S Afr J Bot 2008, 74:572-576.

32. Watcho P, Kamtchouing P, Sokeng S, Moundipa PF, Tantchou J, Essame JL, Koueta N: Reversible antispermatogenic and antifertility activities of Mondia whitei L. in male albino rat. Phytother Res 2001, 15:26-29.

33. Jones GP, Rao KS, Tucker DJ, Richardson B, Barnes A, Rivett DE: Antimicrobial activity of santalbic acid from the oil of Santalum acuminatum (Quandong). Int J Pharmacogn 1995, 33:120-123.

34. Cantrell CL, Berhow MA, Phillips BS, Duval SM, Weisleder D, Vaughn SF: Bioactive crude plant seed extracts from the NCAUR oilseed repository. Phytomedicine 2003, 10:325-333.

35. Das J, Lahan JP, Srivastava RB: Solanum melongena: A potential source of antifungal agent. Indian J Microbiol 2008, 50:62-69.

36. Gbewonyo WSK, Candy DJ: Chromatographic isolation of insecticidal amides from Piper guineense roots. J Chromatogr A 1992, 607:105-111.

37. N'dri K, Bosson KA, Mamyrbekova-Bekro JA, Jean N, Bekro YA: Chemical composition and antioxidant activities of essential. EurJ Sci Res 2009, 37:311-318.

38. Kouokam JC, Jahns T, Becker H: Antimicrobial activity of the essential oil and some isolated sulfur-rich compounds from Scorodophloeus zenkeri. Planta Med 2002, 68:1082-1087.

39. Viveiros M, Jesus A, Brito M, Leandro C, Martins M, Ordway D, Molnar M, Molnar J, Amaral L: Inducement and Reversal of Tetracycline Resistance in Escherichia coli K-12 and Expression of Proton Gradient-Dependent Multidrug Efflux Pump Genes. Antimicrob Agents Chemother 2005, 49:3578-3582

40. Elkins $C A$, Mullis LB: Substrate competition studies using whole-cell with the major tripartite multidrug efflux pumps of Escherichia coli. Antimicrob Agents Chemother 2007, 51:923-929.

41. Baglioni P, Bini L, Liberatori S, Pallini V, Marri L: Proteome analysis of Escherichia coli W3110 expressing an heterologous sigma factor. Proteomics 2003, 3:1060-1065.

42. Ghisalberti D, Masi M, Pagès J-M, Chevalier J: Chloramphenicol and expression of multidrug efflux pump in Enterobacter aerogenes. Biochem Biophys Res Commun 2005, 328:1113-1118.

43. Malléa M, Mahamoud A, Chevalier J, Alibert-Franco S, Brouant P, Barbe J, Pagès JM: Alkylaminoquinolines inhibit the bacterial antibiotic efflux pump in multidrug-resistant clinical isolates. Biochem J 2003, 376:801-805.

44. Pradel E, Pagès J-M: The AcrAB-TolC efflux pump contributes to multidrug resistance in the nosocomial pathogen Enterobacter aerogenes. Antimicrob Agents Chemother 2002, 46:2640-2644.

45. Chevalier J, Pagès J-M, Eyraud A, Malléa M: Membrane permeability modifications are involved in antibiotic resistance in Klebsiella pneumoniae. Biochem Biophys Res Commun 2000, 274:496-499.

46. Tran QT, Mahendra KR, Hajjar A, Ceccarelli M, Davin-Regli A, Winterhalter M, Weingart $\mathrm{H}$, Pagès JM: Implication of Porins in $\beta$-Lactam Resistance of Providencia stuartii. J Biol Chem 2000, 285:32273-32281.

\section{Pre-publication history}

The pre-publication history for this paper can be accessed here: http://www.biomedcentral.com/1472-6882/11/104/prepub

\section{doi:10.1186/1472-6882-11-104}

Cite this article as: Fankam et al:: Antibacterial activities of selected Cameroonian spices and their synergistic effects with antibiotics against multidrug-resistant phenotypes. BMC Complementary and Alternative Medicine 2011 11:104. 